Research Article

\title{
Comparative Efficacy of Fungicides against Charcoal Rot of Sunflower with the Evaluation of Different Respective Plant Traits under Greenhouse Conditions
}

\author{
Habiba ur Rehman, Muhammad Usman Ghazanfar and Waqas Raza*
}

Department of Plant Pathology, College of Agriculture, University of Sargodha, Sargodha 40100, Pakistan.

\begin{abstract}
The following research was designed to evaluate the most appropriate concentration of two different fungicides against the charcoal rot of sunflower caused by Macrophomin phaseolina under greenhouse conditions. The treatments viz. Success, Nativo and Control with the concentrations of 2, 4 and $6 \mathrm{mM}$ were used with three replications under completely randomized design in greenhouse conditions. Nativo had given the most significant results in all studied traits as compared to all other treatments at the concentration of $6 \mathrm{mM}$. The results showed that Nativo exhibited the maximum germination \% (71.47), seedling length (23.67, 35.00 and $47.33 \mathrm{~cm})$, number of leaves/plant $(6.33,7.67$ and 11.33), minimum disease incidence (12.33, 11.12 and $10.13 \%)$, minimum disease severity (26.80, 24.67 and $11.37 \%)$ and maximum plant survival $(89.62,94.35$ and $98.37 \%)$ at 15, 30 and 45 days after treatment, respectively. The application of Success @ $6 \mathrm{mM}$ was also good but lowers than the Nativo. The poor performance and maximum disease incidence and disease severity were recorded from the controlled pots. Among all the treatments the application of Nativo $@ 6 \mathrm{mM}$ had given maximum control of charcoal rot. So, it suggested that the application of Nativo@6 mM may be best for the control of charcoal rot.

Received | October 08, 2020; Accepted | March 15, 2021; Published | June 24, 2021

*Correspondence | Waqas Raza, Department of Plant Pathology, College of Agriculture, University of Sargodha, Sargodha 40100, Pakistan; Email:waqasraza61@yahoo.com

Citation | Rehman, H., M.U. Ghazanfar and W. Raza. 2021. Comparative efficacy of fungicides against charcoal rot of sunflower with the evaluation of different respective plant traits under greenhouse conditions. Sarhad Journal of Agriculture, 37(3): 807-817.

DOI | https://dx.doi.org/10.17582/journal.sja/2021/37.3.807.817

Keywords | Sunflower, Charcoal rot, Fungicides, Doses, Management
\end{abstract}

\section{Introduction}

Qunflower scientifically named as Helianthus Sannuus L. belongs to the family Asteraceae and genus Helianthus. Wild parents of sunflower are quite resistant whereas edible sunflower is susceptible to different diseases among which charcoal rot of sunflower caused by Macrophomina phaseolina is most devastating disease (Khan, 2007). There is huge decrease in the production that is due to many biotic and abiotic diseases among which charcoal rot caused by Macrophomina phaseolina is most common disease that has caused lower yield of sunflower in Pakistan and around the world. From abiotic factors drought is one of the main causes of yield loss in sunflower crop (Škorić, 2016). In Pakistan charcoal rot of sunflower was first time reported in 1984 from Faisalabad (Mirza, 1984) and afterward it was reported from other areas of Sindh, KPK and Punjab as a serious threat to sunflower crop (Steven et al., 1987). The first survey of sunflower crop was conducted by Mirza and Beg (1983) in the northern and central areas of Pakistan and according to them up to $90 \%$ losses of yield was caused by Macrophomina phaseolina (Ullah 
et al., 2011).

M. phaseolina cause discoloration of seed and increase of free fatty acids (Ataga and Akueshi, 1986) and it remain viable as sclerotia and the survival may extend up to 4 years in crop residues and soil. Infected plants were giving silvery-grey look and died prematurely. The conidia of $M$. phaseolina are aseptate, thin-walled, elliptical and hyaline. When the conditions are favorable hyphae of the fungus grow and produce the sclerotia that infect the roots of host crop through chemical softening or mechanical pressure by penetration of plant cell wall. The pith of the stem in its lower part was observed to be compressed into horizontal layers and micro sclerotia of black color were also seen there (Bokor, 2007). Helianthus annus $L$. is parasitized by larvae of sunflower stem weevil scientifically named as Cylindrocopturus adspersus and cause brown to black discoloration of stalk. Fusarium roseum, F. solani, Alterneria alternate, Rbizopus arrbizus, Phoma macdonaldi, were isolated from the infected discolored part of the sunflower stalk. Cylindrocopturus adspersus (sunflower stem weevil) is the vector of charcoal rot of sunflower caused by $M$. phaseolina (Yang et al., 1983). A number of disease management strategies such as biological control, soil solarization, use of resistant varieties, cultural practices, systemic induce resistance etc. are being used for the management of this disease but all these methods require long time and depend upon high accomplishment (Infantino et al., 2006) whereas chemical method provide instant protection of plant along with enhanced yield and production.

\section{Materials and Methods}

The experiment was performed to check the efficient fungicide against the $M$. phseolina in greenhouse. The experiment was performed in the green house at the College of Agriculture, University of Sargodha.

\section{Material required}

- $\quad$ Pots $=30$

- Sorghum seed: $01 \mathrm{~kg}$

- Fungicide: Nativo and Success

- Fungus culture of $M$. phaseolina

\section{Preparation of soil for pot culture}

For testing fungicide effectiveness against $M$. phaseolina in pots, sunflower surface sterilized seeds were treated with the 2, 4 and $6 \mathrm{mM}$ of both fungicides i.e. Nativo and Success as slurry method. While the sterile water is used for control seed treatment. Ten seeds in three replications were planted in the sterile pots having sand and soil mixture @ 1:1 (v:v) amended with seed of sunflower with $M$. phaseolina colonization@2g/kg of soil. After sowing pots were placed at $30^{\circ} \mathrm{C}$ in growth room (Iqbal and Mukhtar, 2020). The data was recorded for germination $\%$ and plant survival after 20 days of treatment.

\section{Procedure of sowing}

Thirty pots were taken and filled with the soil i.e. three pots for each treatment $(2,4$ and $6 \mathrm{mM})$. Three replications were formed for each dose resulting total 27 pots for all treatments. Three pots were kept as a control (no fungicide treatment) but the fungal inoculum was added. Seven days before the planting of seeds inoculum grown on sorghum after crushing was added @ $2 \mathrm{~g} / \mathrm{kg}$ of soil in pots. Sorghum seeds were autoclaved and placed in jars with one to two fungal plugs of seven-day old culture of $M$. phaseolina. On the top of inoculum 3 to $5 \mathrm{~cm}$ thick layer of sand was added for growth and incidence of $M$. phaseolina. Sunflower seeds were sterilized with 5\% chloroform and planted in 1 to $2 \mathrm{~cm}$ depth at adequate soil moisture after 7 days of soil inoculation. When the symptoms appeared on the seedlings, three doses of Nativo and Success i.e. 2, 4 and $6 \mathrm{mM}$ were formed. Each dose was sprayed on 9 pots with repeat of three replications of each concentration.

\section{Experimental design and layout}

The experiment was laid under CRD with two replications. The plants were grown in the pots and treated with the $M$. phseolina to develop disease symptoms. Then the infected plates were treated with Nativo and Success @ 2,4 and 6 mM separately on five pots for each treatment. The control was not sprayed with any chemical.

\section{Data recording}

The data was recorded after the appearance of disease symptoms on the control plot for the following traits.

\section{Germination \%}

The germination percentage was recorded from the following formula.

$$
\text { Germination }(\%)=\frac{\text { No.of seeds germinated }}{\text { Total no.of seeds } \text { planted }} \times 100
$$


Seedling length

The seedling length was measured 20 days after germination with the help of measuring tape from each replication and treatment separately.

\section{No. of leaves/plant}

The number of leaves/plant was manually counted 20 days after germination from each replication and treatment separately.

\section{Disease incidence}

The disease incidence was measured by the following formula (Lakhran et al., 2018).

$$
\text { Disease incidence }(\%)=\frac{\text { No.of diseased plants }}{\text { Total no. of plants }} \times 100
$$

\section{Disease severity}

Each treatment efficacy was measured by plant disease severity. Which measures the disease intensity at the specific plant growth stages (Manici et al., 1992). The disease severity was measured by the following formula.

Disease severity $=\frac{\text { Summation of numerical rating }}{\text { Number of plants exam } \times \text { Max. disease score }} \times 100$

\section{Plant survival}

Plan survival percentage was recorded from the following formula.

$$
\text { Plant survival }(\%)=\frac{\text { No. of plants survived on } 20 \text { th day }}{\text { Total no. of plants germinated }} \times 100
$$

\section{Statistical analysis}

Statistical data analysis was performed using Statistix 8.1 language. Treatment means were compared by Least Significant Difference (LSD) test under completely randomized design (CRD) (Steel et al., 1997).

\section{Results and Discussion}

The green house experiment was performed, and data was recorded for the growth and disease related traits. It was recorded that all the studied traits differed significantly among the treatments.

\section{Germination \%}

The germination \% significantly affects the yield of the crop. It is essential to maintain optimum plant population. As the genotypes which have poor germination percentage showed poor performance and disliked by the farmers. The germination $\%$ ranged from $51.30 \%$ to $71.47 \%$. The maximum germination $\%(71.47 \%)$ was observed from the application of Nativo@6 mM, which was followed by Success@6 $\mathrm{mM}(67.60 \%)$. The lowest germination \% (51.30 \%) was observed under control. It was evident that the application of fungicide enhanced the germination \% compared to control. The mean comparison showed insignificant differences among treatment means for germination \% except for control, Success @ $2 \mathrm{mM}$ and Nativo@6mM that showed significant differences for germination \% (Figure 1).

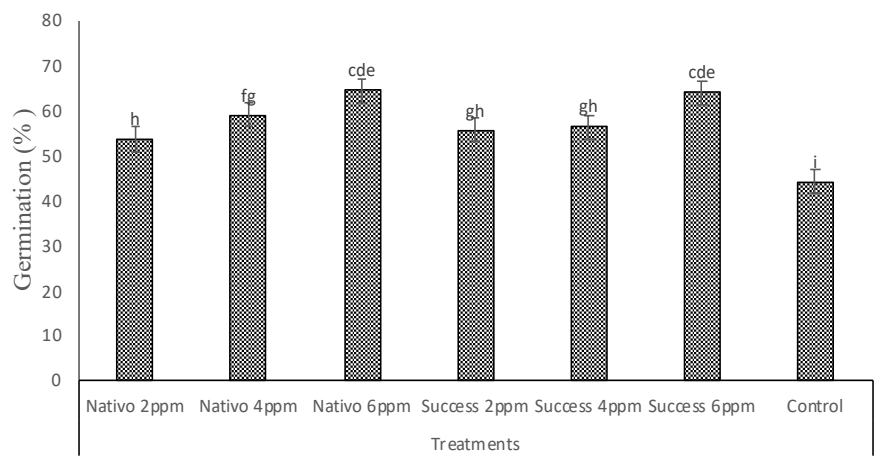

Figure 1: Mean performance of different chemical for germination percentage (\%) at $15^{\text {th }}$ day of treatment.

\section{Seedling length $(\mathrm{cm})$}

Seedling length is the most important parameter. More the seedling length results more capture of light from the sun compared to weeds. Secondly more seedling length showed better crop stand. At 15 days after the treatment (Figure $2 \mathrm{a}$ ) the maximum seedling length $(23.67 \mathrm{~cm})$ was recorded from Nativo @6 mM, which was followed by Success@6 mM and Nativo@ 4 mM $(21.33 \mathrm{~cm})$. The lowest seedling length $(14.87 \mathrm{~cm})$ was observed under control. In case of 30 days after treatment (Figure 2b) the maximum seedling length $(35.00 \mathrm{~cm})$ was recorded from Nativo@6 mM. The minimum seedling length $(17.99 \mathrm{~cm})$ was observed under control. At 45 days after treatment (Figure 2c) the maximum seedling length $(47.33 \mathrm{~cm})$ was recorded from Nativo@6 $\mathrm{mM}$. The minimum seedling length $(31.33 \mathrm{~cm})$ was observed under control. It was evident that the application of fungicide enhanced the seedling length and better crop stand compared to control. Fungus become quickly established at seedling stage within 24 to 48 hours followed by low temperature and high moisture. The mean comparison showed insignificant differences among treatment means for seedling length (Figure 2). 


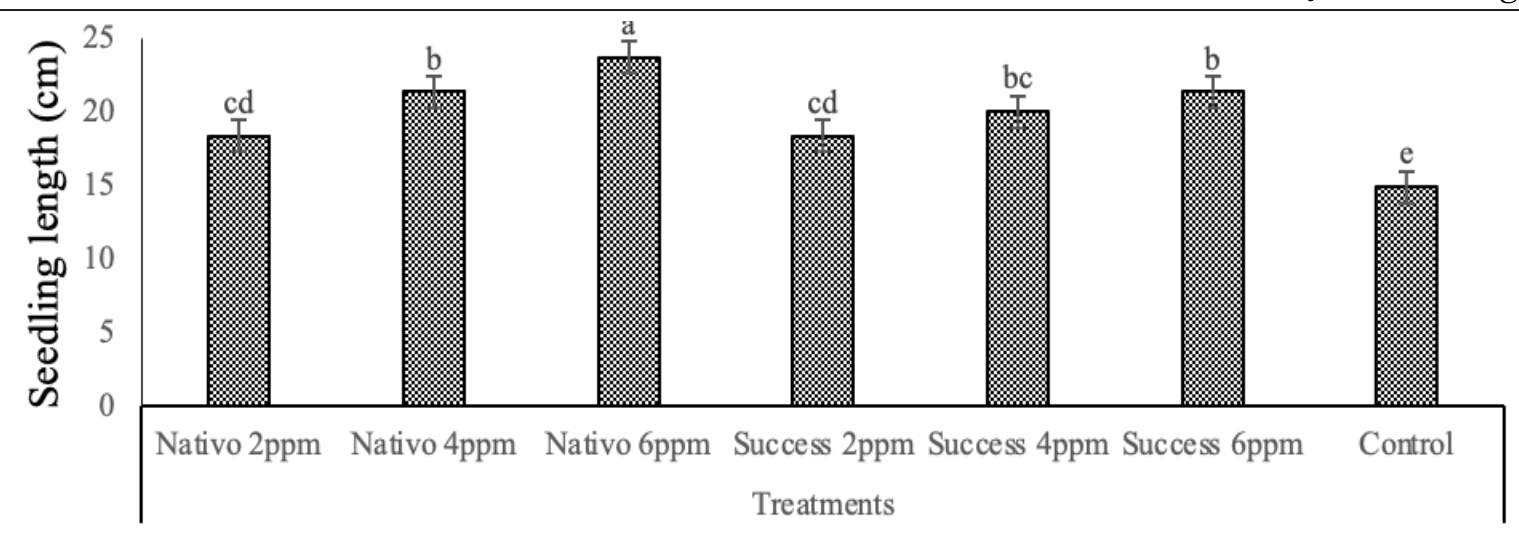

a

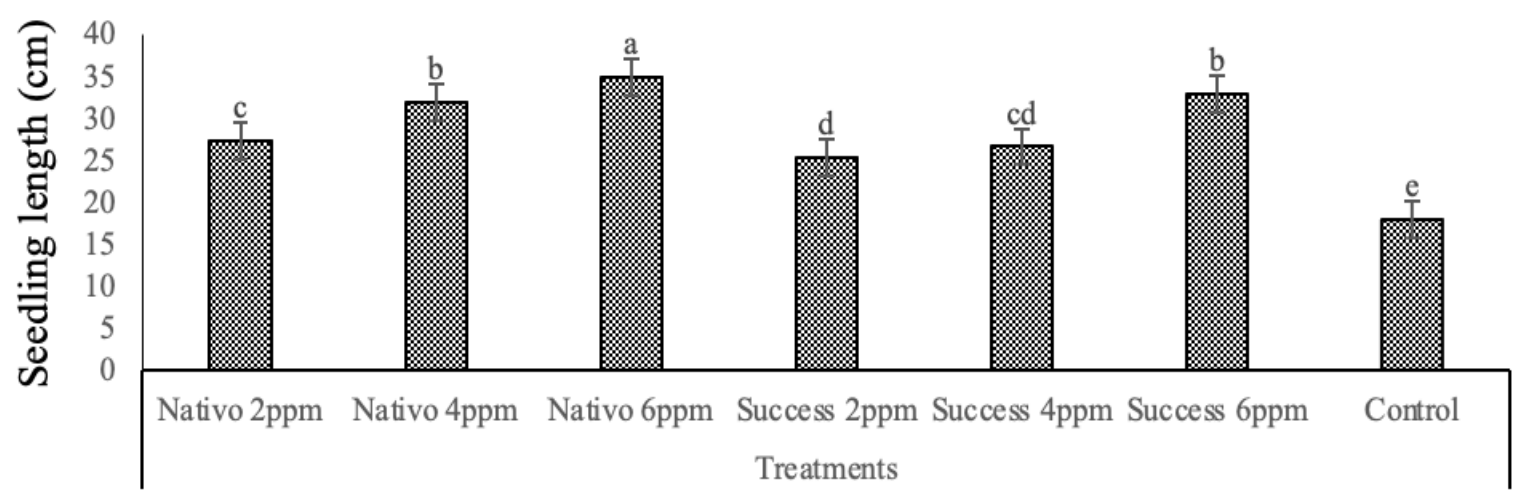

b

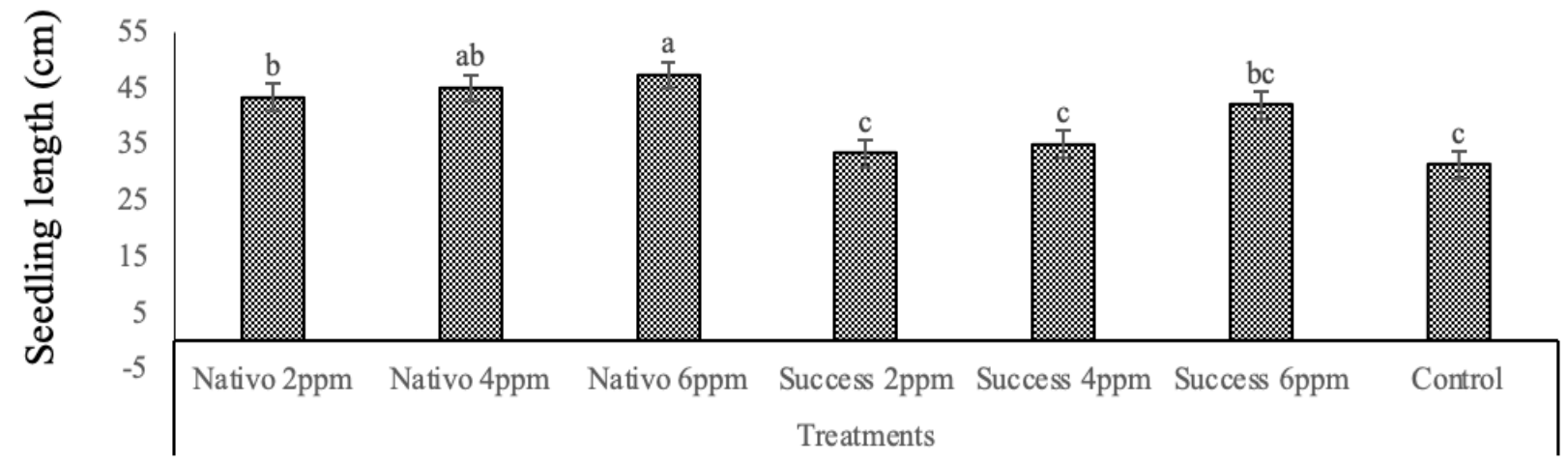

c

Figure 2: Mean performance of different chemical for seedling length $(\mathrm{cm})$ at $15^{\text {th }}$ day (a) $30^{\text {th }}$ day (b) and $45^{\text {th }}$ day $(c)$ of treatment.

No. of leaves/plant (NLP)

No. of leaves / plant are more essential for determining the growth and productivity of a crop. As more the number of leaves more will be the photosynthesis thus more will be the accumulation of photosynthates and more the crop yield. At 15 days after the treatment (Figure 3a) the highest NLP (6.33) was seen from Nativo@6 mM, which was followed by Success@ $6 \mathrm{mM}$ (6.00). The lowest NLP (2.58) was observed under control. In case of 30 days after treatment (Figure 3b) the maximum NLP (7.67) was recorded from Nativo@6 mM. The minimum number of leaves/plant (4.73) was observed under control. At 45 days after treatment (Figure 3c) the maximum NLP (11.33) was recorded from Nativo @ 6 mM. The minimum NLP (6.34) was observed under control. It was evident that the application of fungicide enhanced the crop growth, NLP and reduces disease incidence 


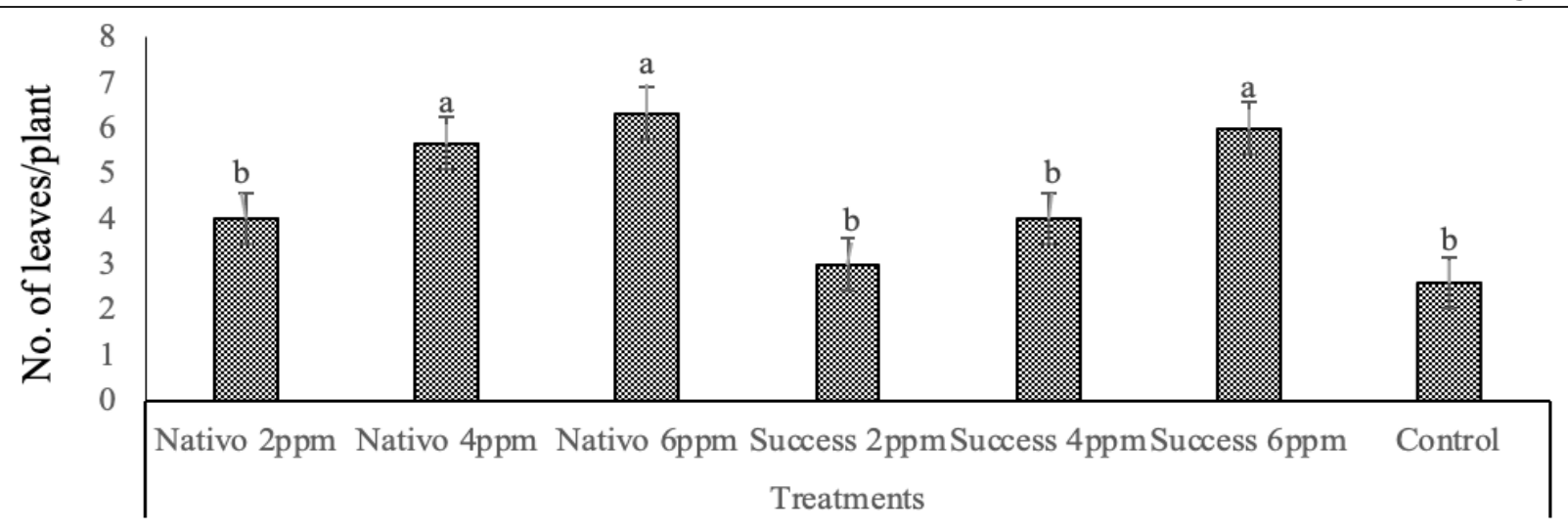

a

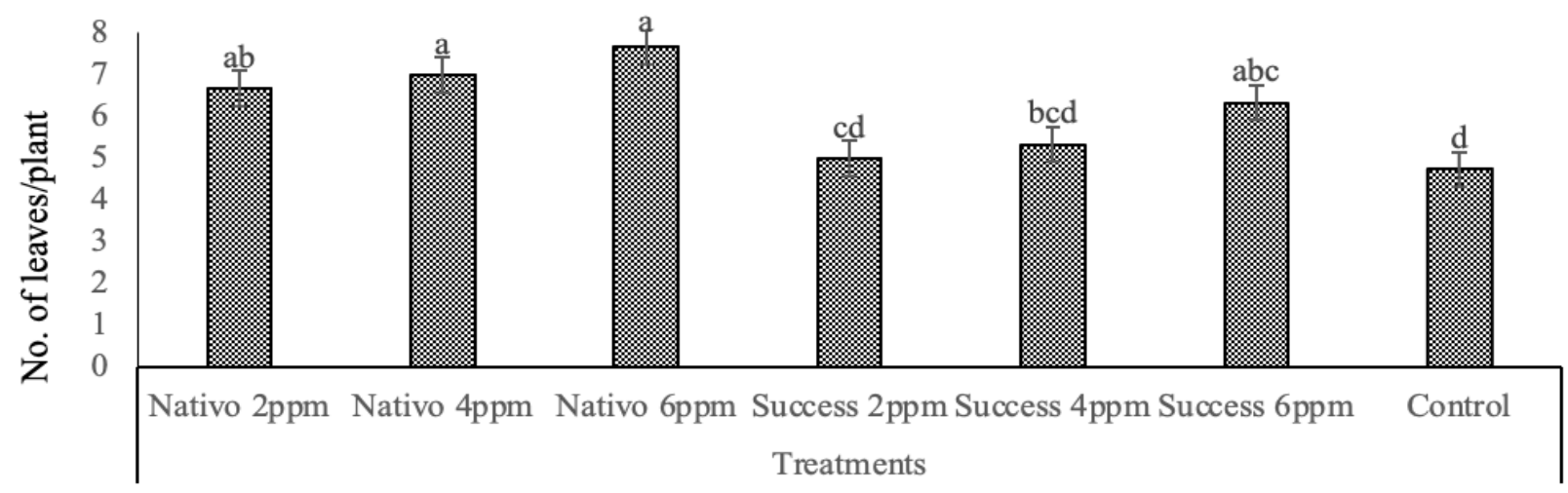

b

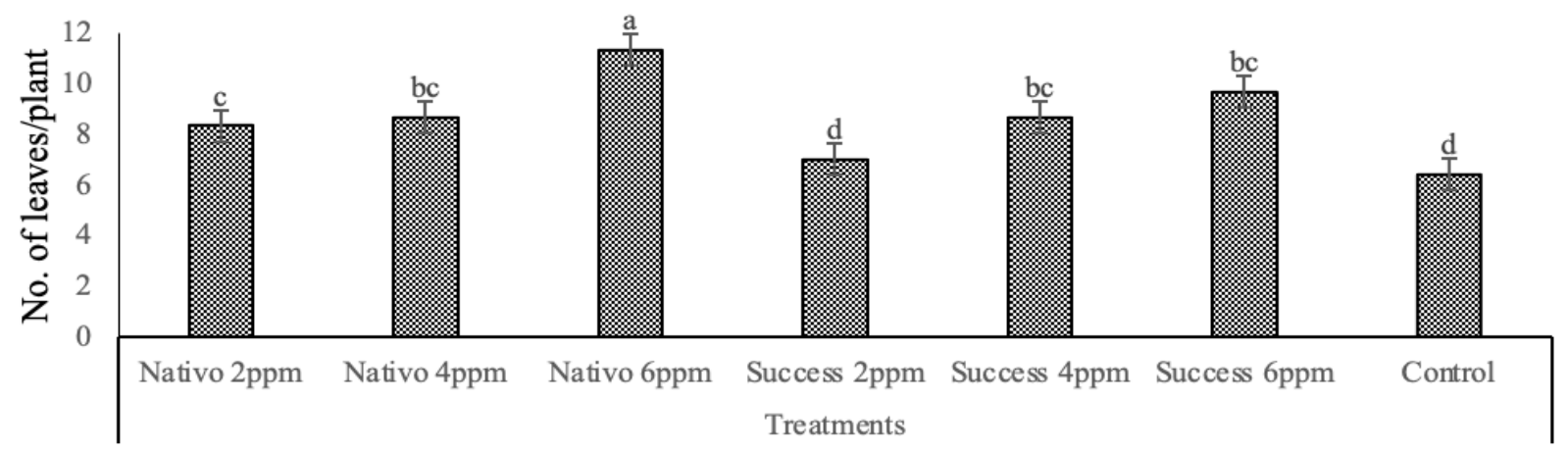

c

Figure 3: Mean performance of different chemical for no. of leaves/plant at $15^{\text {th }}$ day (a) $30^{\text {th }}$ day (b) and $45^{\text {th }}$ day (c) of treatment.

compared to control. The mean comparison showed insignificant differences among treatment means for NLP (Figures 3).

\section{Disease incidence (\%)}

At 15 days after the treatment (Figure 4a) the lowest disease incidence (12.33\%) was recorded from Nativo@6 mM, which was followed by Success@ $6 \mathrm{mM}$ (17.20\%). The maximum disease incidence $(63.20 \%)$ was observed under control. In case of 30 days after treatment (Figure $4 \mathrm{~b}$ ) the lowest disease incidence (11.12\%) was recorded from Nativo @ 6 $\mathrm{mM}$. The highest disease incidence $(69.13 \%)$ was observed under control. At 45 days after treatment (Figure 4c) the minimum disease incidence (10.13\%) was recorded from Nativo @ 6 mM. The maximum disease incidence $(79.73 \%)$ was observed under control. It was evident that the application of fungicide significantly reduces disease incidence compared to control. The mean comparison showed significant differences among treatment means for disease incidence (Figure 4). 


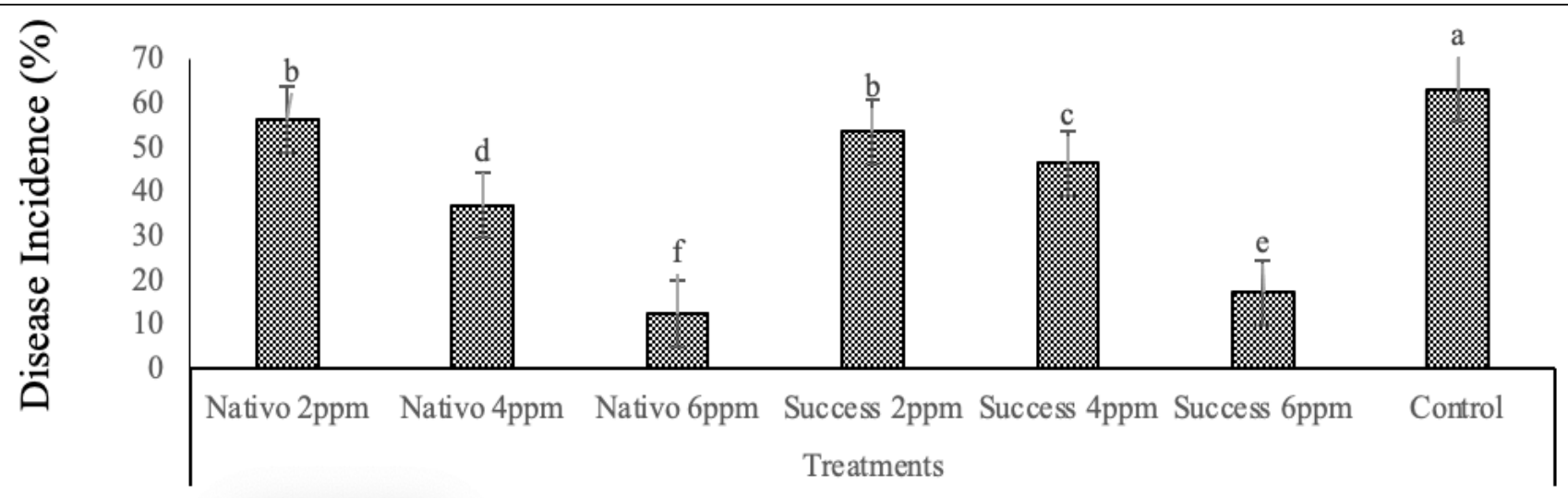

a

\section{Chart Area}

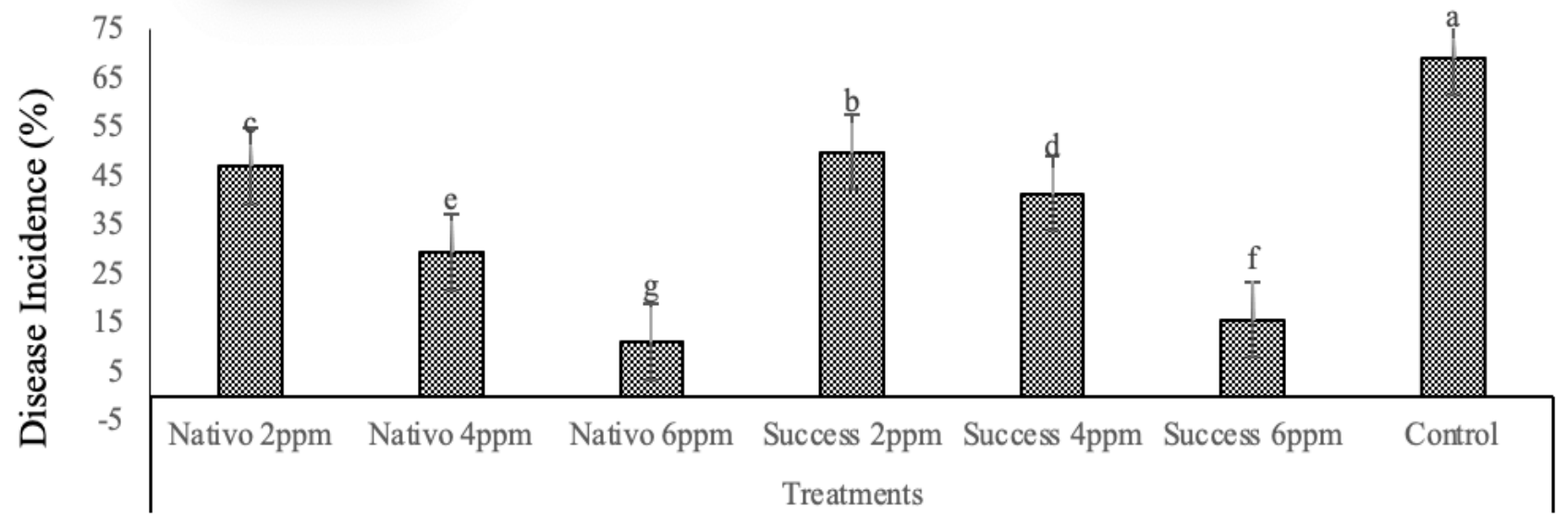

b

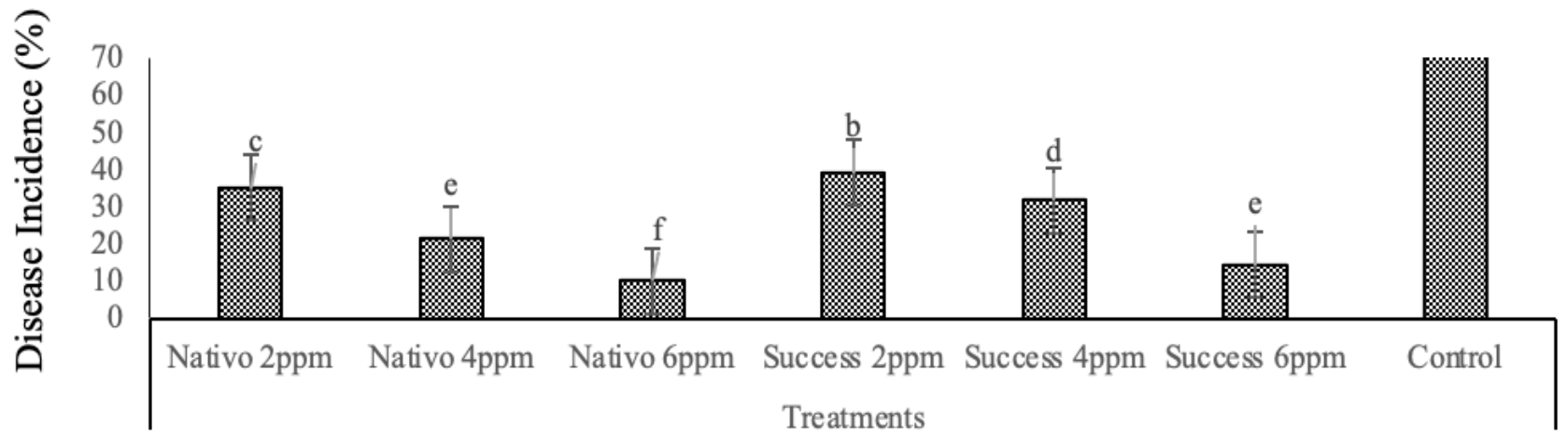

Figure 4: Mean performance of different chemical for disease incidence (\%) at $15^{\text {th }}$ day (a) $30^{\text {th }}$ day (b) and $45^{\text {th }}$ day (c) of treatment.

\section{Disease severity}

At 15 days after the treatment (Figure 5a) the lowest disease severity $(26.80 \%)$ was recorded from Nativo @ 6 mM, which was followed by Nativo@ $4 \mathrm{mM}$ (38.93\%). The maximum disease severity $(133.94 \%)$ was observed under control. In case of 30 days after treatment (Figure 5b) the lowest disease severity (24.67 \%) was recorded from Nativo@ 6 mM. The highest disease severity (124.98\%) was observed under control. At 45 days after treatment (Figure 5c) the minimum disease severity $(11.37 \%)$ was recorded from Nativo@6 mM. The maximum disease severity (110.01\%) was observed under control. It was evident that the application of fungicide significantly reduces disease severity compared to control. The mean comparison showed significant differences among treatment means for disease severity (Figure 5).

\section{Plant survival}

At 15 days after the treatment (Figure 6a) the 


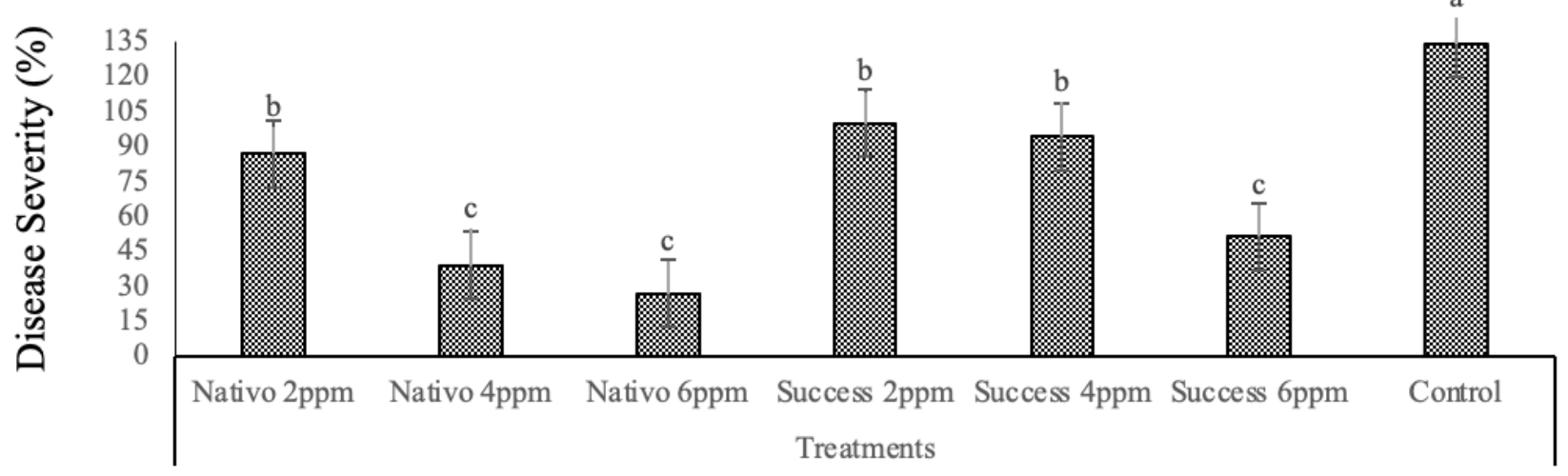

$\mathbf{a}$

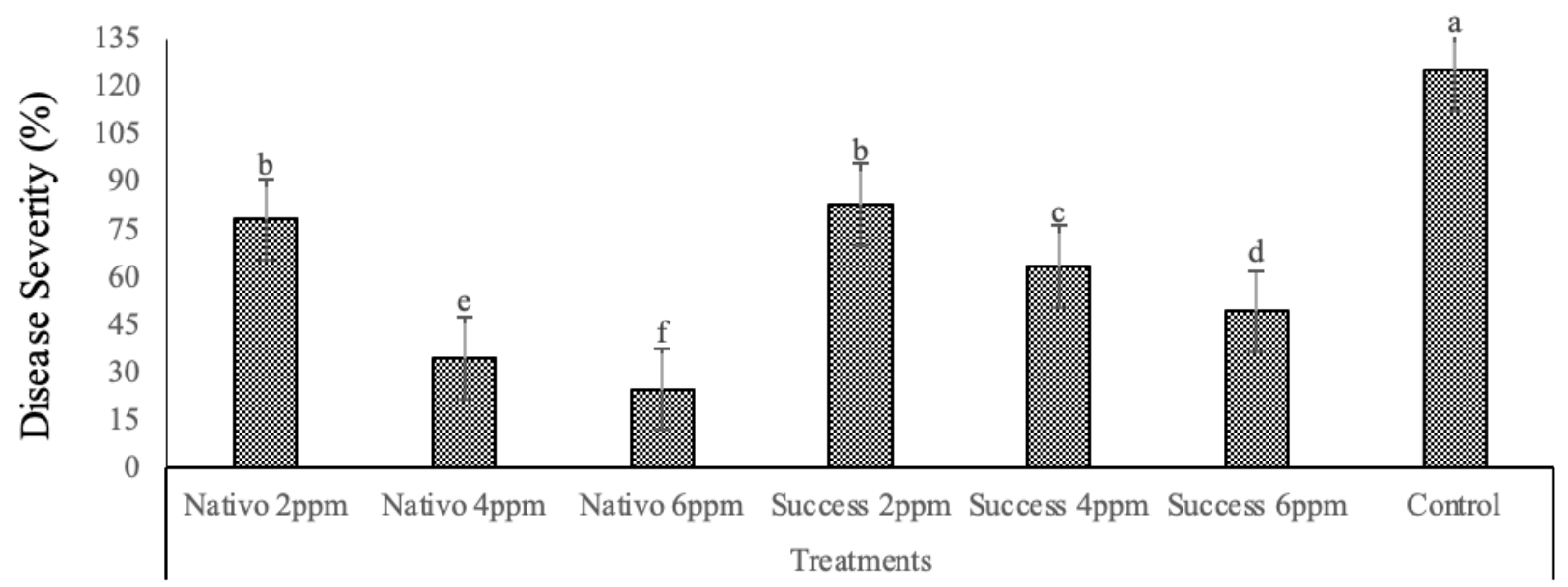

b

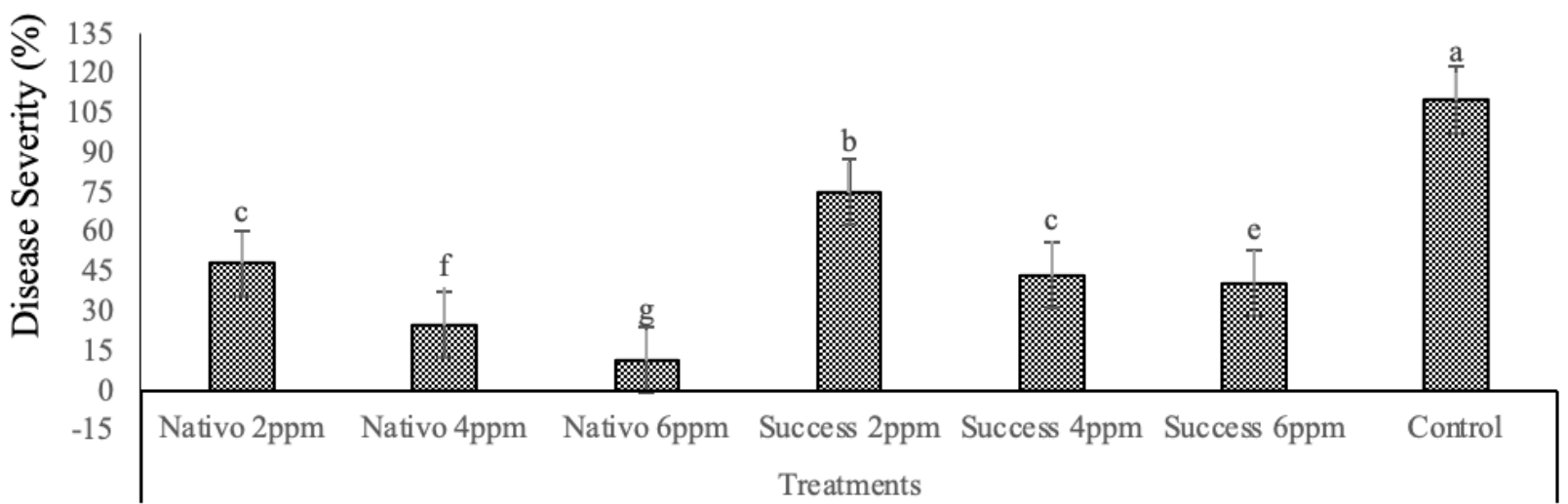

c

Figure 5: Mean performance of different chemical for disease severity (\%) at $15^{\text {th }}$ day (a) $30^{\text {th }}$ day (b) and $45^{\text {th }}$ day (c) of treatment.

maximum plant survival (89.62\%) was recorded from Nativo@6 mM, which was followed by Nativo@ 4 $\mathrm{mM}(87.57 \%)$. The minimum plant survival (56.02 $\%)$ was observed under control. In case of 30 days after treatment (Figure 6b) the maximum plant survival (94.35\%) was recorded from Nativo @ 6 mM. The lowest plant survival (69.57\%) was observed under control. At 45 days after treatment (Figure 6c) the maximum plant survival (98.87 \%) was recorded from Nativo@6 mM. The minimum plant survival (73.78 $\%)$ was observed under control. It was evident that the application of fungicide significantly reduces plant survival compared to control. The mean comparison showed significant differences among treatment means for plant survival (Figure 6). 


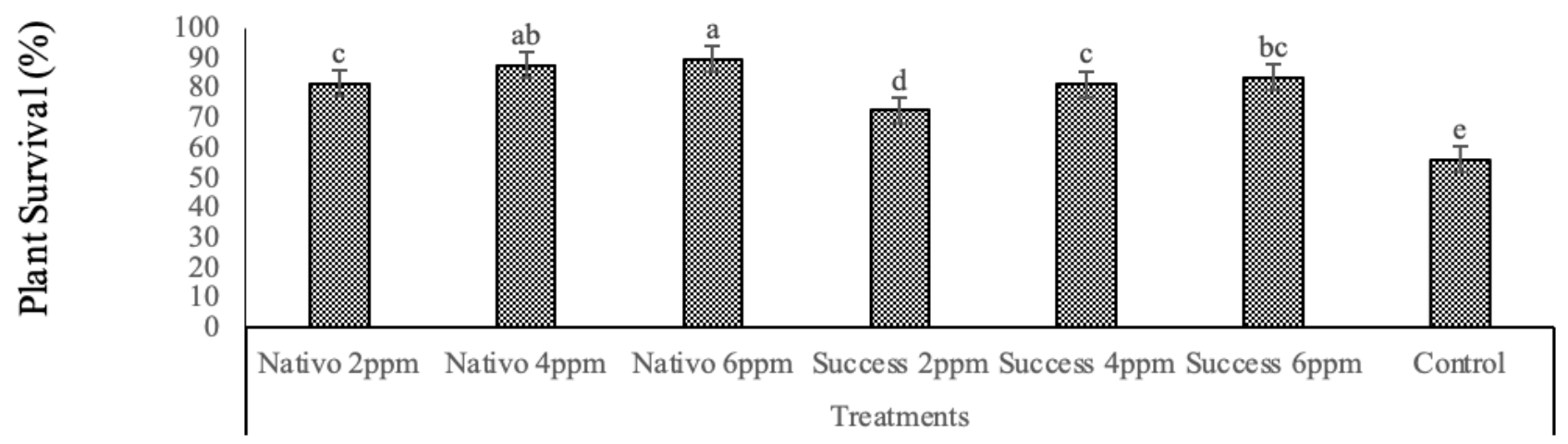

$\mathbf{a}$

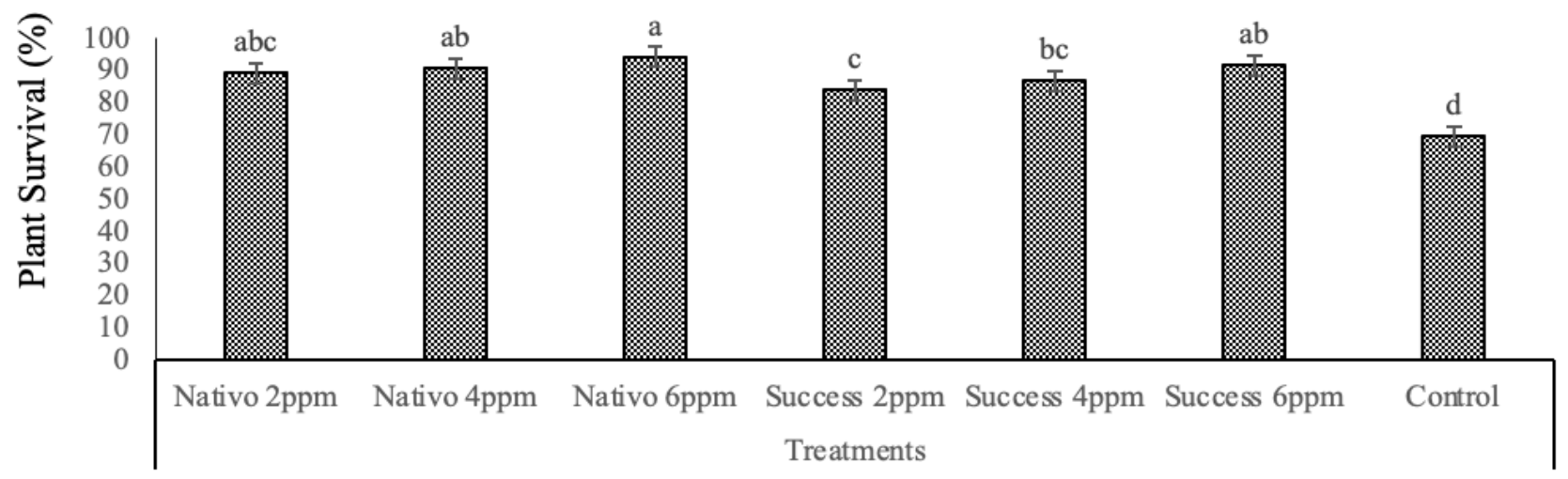

b

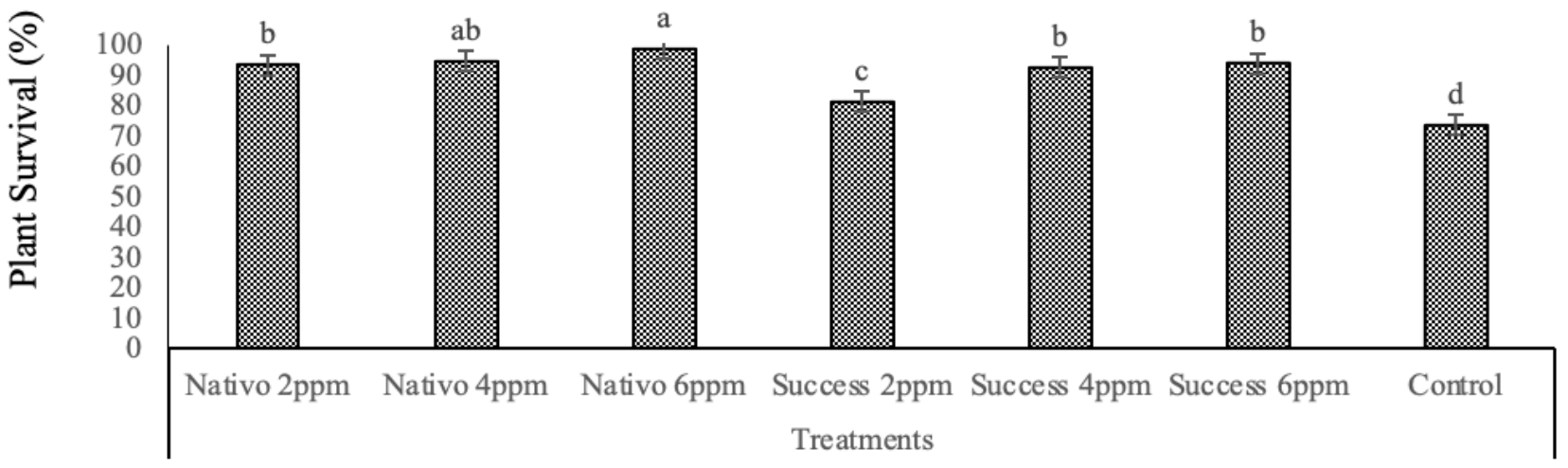

Figure 6: Mean performance of different chemical for plant survival (\%) at $15^{\text {th }}$ day (a) $30^{\text {th }}$ day (b) and $45^{\text {th }}$ day (c) of treatment.

Charcoal rot of sunflower caused by $M$. phaseolina affect the yield and quality of sunflower in sunflower growing areas of Pakistan. France, Italy, Israel and Germany are four leading countries in seed production of sunflower whereas, Pakistan's average yield of sunflower is much less than these leading countries (Ullah et al., 2011). The initial symptoms of disease show leaf yellowing that results in wilting and eventually cause plant death (Islam et al., 2012).
If the resistant germplasm is not available, chemical management through fungicides is a quick and readily available method to decrease the soil borne inoculum (Reznikov et al., 2016).

Charcoal rot of sunflower caused by Macrophomina phaseolina affect the yield and quality of sunflower in sunflower growing areas of Pakistan. France, Italy, Israel and Germany are four leading countries in seed 
production of sunflower, with average yield 2334, 2228, 2417, and $2476 \mathrm{~kg}$ /acre respectively whereas, Pakistan's average yield of sunflower is much less than these leading countries (Ullah et al., 2011). Total production of sunflower in Pakistan during 2010 was 325,478 tons which has been decreased to a larger extent in 2017 during which production recorded was 104,000 tons (FAOSTAT, 2017).

The pathogen form sclerotia that can survive in soil or seed as well and cause increase of free fatty acid and discoloration of seed. Hyphaeof the fungus first invade the plant's cortical tissues that results in formation of sclerotia eventually charcoal rot disease is caused. Sclerotia produced aregray-black in color and the symptoms can be seen on infected area. Sunflower crop showed symptoms in some fields caused by charcoal rot fungus during second half month of August. The initial symptoms of disease show leaf yellowing that results in wilting and eventually cause plant death (Islam et al., 2012). If the resistant germplasm is not available, chemical management through fungicides is a quick and readily available method to decrease the soil borne inoculum (Reznikov et al., 2016).

In current studies two fungicides Nativo and Success were assessed against the charcoal rot of sunflower. Greenhouse inoculation of sunflower seeds with Macrophomina phaseolina affected all studied traits, as compared with the noninoculated control pots. Nativo expressed least disease incidence, disease severity $(10.13 \%$ and $11.37 \%$ respectively at concentration of $6 \mathrm{mM}$ after $45^{\text {th }}$ day) by hindering the growth and development of pathogen. It disturbs the ionic concentration of pathogen sclerotia and it attach through the formation of covalent bond (E1Fiki et al., 2004b). The findings of above studies are in line with the research of Bashir et al. (2017) who evaluated Antracol, Topsin-M, Mancozeb, Score, Topas and Nativo (active ingridients; Tebuconazole $50 \%+$ Trifloxystrobin 25\%) at the concentration of 150,250 , and $350 \mathrm{ppm}$ against charcoal rot caused by Macrophomina phaseolina and results showed that Nativo performed well in the reduction of disease incidence as compared to control. Iqbal and Mukhtar (2020) evaluated nine different fungicides @ 50, 100 and 150ppm against charcoal rot pathogen and research showed that plant survival and germination were directly corelated with the concentration of the fungicide i.e. minimum plant survival and germination was assessed @50ppm and maximum was recorded where the seeds were treated @ 150 ppm. Carbendazim and Benomyl @ 150ppm gave highest fungal inhibition of $79.11 \%$ and $83.89 \%$, respectively whereas maximum plant survival was also recorded at the same concentration i.e. $66.67 \%$ and $76.67 \%$, respectively.

Smith (1969) and Meyer et al. (1974) described that viable sclerotial population in the soil is positively correlated with increase or decrease in disease severity whereas mycelium of the fungus present in soil is not assessed as a vital source of inoculum. Sackston (1981) explained through his research that disease severity and disease incidence are corelated with the cultural practice being used in the field and the climatic factors. Cohen et al. (2012) conducted an experiment with non-grafted plants, melons were treated with azoxystrobin solely or in combination with medenoxam or chlorothalonil and it resulted in $5 \%$ disease incidence reduction than $45 \%$ in the control plants.

Maximum seedling length was recorded under treatment with Nativo @6mM at $45^{\text {th }}(47.33 \mathrm{~cm})$ day as compared to the control and other treatments. Khan (2007) conducted a research and result showed that if the infected plant withstands the seedling attack and survives from seed mortality the pathogen progress slowly toward above ground parts and eventually the symptoms can be observed clearly at grain formation stage.

\section{Conclusions and Recommendations}

The research was designed to evaluate the most appropriate concentration of fungicides against the charcoal rot of sunflower in greenhouse conditions. Among used treatments, the application of Nativo had given maximum control of charcoal rot. So, it recommended that the application of Nativo@6 mM can be best possible control against charcoal rot.

\section{Novelty Statement}

The experiment was performed to check the efficacy of fungicides against the $M$. phseolina in greenhouse conditions which was never explored comprehensively in Sargodha region. 


\section{Author's Contribution}

Habiba ur Rehman: Conceived and designed research and wrote the manuscript.

Muhammad Usman Ghazanfar: Supervised the experiment and improved the draft.

Waqas Raza: Analyzed the data, help in conduct of experiments and submission of paper.

\section{Conflict of interest}

The authors have declared no conflict of interest.

\section{References}

Ataga, A.E. and C.O. Akueshi. 1986. Changes in oil and free fatty acid contents of sunflower seeds inoculated with Alternaria tenuis Auct, Curvularia lunata (Waiker) charcoal rot on sunflower 225 Boedijn, Fusarium moniliforme Sheld, and Macrophomina phaseolina (Tassi) Goid. Phytopathol. Mediterr., 25: 44-46.

Bashir, M.R., A. Mehmood, M. Sajid, M.A. Zeshan, M. Mohsin, Q.A. Khan and F.A. Tahir. 2017. Exploitation of new chemistry fungicides against charcoal rot of sesame caused by Macrophomina phasiolina in Pakistan. Pakistan J. Phytopathol., 29(2): 257-263. https://doi. org/10.33866/phytopathol.029.02.0404

Bokor, P., 2007. Macrophomina phaseolina causing a charcoal rot of sunflower through Slovakia. Biologia, 62(2): 136-138. https://doi. org/10.2478/s11756-007-0020-9

Cohen, R., N. Omari, A. Porat and M. Edelstein. 2012. Management of Macrophomina wilt in melons using grafting or fungicide soil application: pathological, horticultural and economical aspects. Crop Prot., 35: 58-63. https://doi.org/10.1016/j.cropro.2011.12.015

El-Fiki, A., F. Mohamed, A. El-Deeb and M. Khalifa. 2004. Some applicable methods for controlling sesame charcoal rot disease (Macrophomina phaseolina) under greenhouse conditions. Egypt J. Phytopathol., 32: 87-101.

FAO, 2017. Sunflower production in Pakistan. http://www.factfish.com/statistic-country/pakistan/sunflower+seed,+production+quantity. Assessed on 20.12.2019.

Infantino, A., M. Kharrat, L. Riccioni, C.J. Coyne, K.E. McPhee and N.J. Grünwald. 2006. Screening techniques and sources of resistance to root diseases in cool season food legumes. Euphytica, 147: 201-221. https://doi. org/10.1007/s10681-006-6963-z

Iqbal, U. and T. Mukhtar. 2020. Inhibitory effects of some fungicides against Macrophomina phaseolina causing charcoal rot. Pak. J. Zool., 52(2): 709. https://doi.org/10.17582/journal. pjz/20181228101230

Islam, M.S., M.S. Haque, M.M. Islam, E.M. Emdad. A. Halim, Q.M.M. Hossen and M.M. Alam. 2012. Tools to kill: genome of one of the most destructive plant pathogenic fungi Macrophomina phaseolina. BMC Genomics, 13(1): 493. https://doi.org/10.1186/14712164-13-493

Khan,S.N.,2007. Macrophomina phaseolina as causal agent for charcoal rot of sunflower. Mycopath, 5(2): 111-118.

Lakhran, L., R.R. Ahir, M. Choudhary and S. Choudhary. 2018. Isolation, purification, identification and pathogenicity of Macrophomina phaseolina (Tassi) goid caused dry root rot of chickpea. J. Pharm. Phytochem., 7(3): 3314-3317. https://doi.org/10.20546/ ijcmas.2018.707.151

Manici, L.M., C. Cerato and F. Caputo. 1992. Pathogenic and biological variability of Macrophomina phaseolina (Tassi) Goid iso-lates in different areas of sunflower cultivation in Italy. Proc. Int. Sunflower Conf., 1: 779784.

Markell, S., R. Harveson, C. Block and T. Gulya. 2015. Sunflower disease diagnostic series. pp. 1727-19. https://doi.org/10.1016/B978-1893997-94-3.50010-6

Meyer, W.A., J.B. Sinclair and M.N. Khare. 1974. Factors affecting charcoal rot of soybean seedlings. Phytopathology. 64(6): 845-849. https://doi.org/10.1094/Phyto-64-845

Mirza, M.S and A. Beg. 1983. Diseases of sunflower in Pakistan in 1982. Hellia, 6: 55-56.

Mirza, M.S.1984. Occurrence of sunflower diseases in Pakistan in 1980-83. In: Proceedings of the National Sunflower Workshop, PARC, p. 31-32 Reznikov, S., G.R. Vellicce, V. González, V. de Lisi, A.P. Castagnaro and L.D. Ploper. 2016. Evaluation of chemical and biological seed treatments to control charcoal rot of soybean. J. Plant Pathol., 82: 273-280. https://doi. org/10.1007/s10327-016-0669-4

Sackston, W.E., 1981. The sunflower crop and disease: Progress, problems, and prospects. Plant Dis., 65(8): 643-648. https://doi.org/10.1094/ 


\section{PD-65-643}

Škorić, D., 2016. Sunflower breeding for resistance to abiotic and biotic stresses. In: Abiotic and biotic stress in plants-recent advances and future perspectives. Intech Open. https://doi. org/10.5772/62159

Smith, W.H., 1969. Germination of Macrophomina phaseoli sclerotia as effected by Pinus lambertiana root exudate. Can. J. Microbiol., 15(12): 13871391. https://doi.org/10.1139/m69-250

Steel, R.G., J.H. Torrie and D.A. Dickey. 1997. Principal and procedure of statistics: A biometrical approach. $3^{\text {rd }}$ edition. McGraw Hill Book Co., New York.
Steven,M.,M.A.Rana,M.S.Mirza and M.A.Khan. 1987. The survey of sunflower crop in Pakistan. Oilseed Programme, NARC, Islamabad.

Ullah, M.H., M.A. Khan, S.T. Sahi and A. Habib. 2011. Evaluation of antagonistic fungi against charcoal rot of sunflower caused by Macrophomina phaseolina (Tassi) Goid. Afr. Environ. Sci. Technol., 5(8): 616-621.

Yang, S.M., C.E. Rogers and N.D. Luciani. 1983. Transmission of Macrophomina phaseolina in sunflower by Cylindrocopturus adspersus. Phytopathol., 73(10): 1467-1469. https://doi. org/10.1094/Phyto-73-1467 